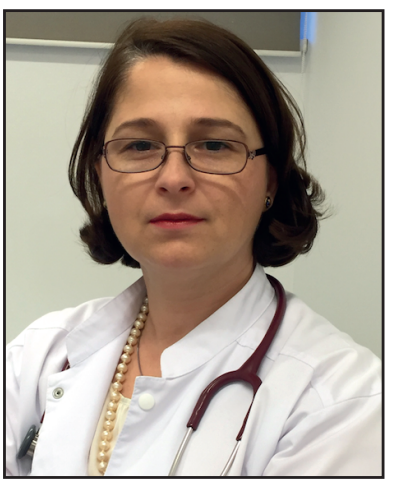

Camelia DIACONU ${ }^{凶}$

International Secretary General of the Balkan Medical Union

President of the Romanian National Section

Secrétaire Général International de l'Union Médicale Balkanique

Présidente de la Section Nationale Roumaine

\section{IS THERE AN IMPLICATION OF INTESTINAL MICROBIOTA IN CARDIOVASCULAR DISEASES?}

Nowadays, more and more evidence points out to the interrelationship between intestinal microbiota and cardiovascular diseases. Gut microbiota is composed of a large number of microorganisms that live in the human gut and are involved in many physiological processes. Changes in the composition and activity of intestinal microbiota may lead or may accelerate the evolution of some cardiovascular diseases. Alterations in the composition of gut microbiota will induce dysbiosis, causing inflammation and initiating the development of cardiovascular diseases. These alterations may be secondary to intestinal infections, exposure to some environmental factors, changes in dietary habits, high stress, use of antibiotics. Studies have shown that gut microbiota is composed of six families, the Firmicutes, Bacteroidetes, Proteobacteria, Actino-bacteria, Fusobacteria, and Verrucomicrobia phyla ${ }^{1}$. These microorganisms are involved in the immune processes of the host, the fight against the pathogenic microorganisms and also in maintaining the integrity of intestinal barriers.

Coronary heart disease and arterial hypertension are chronic diseases with a high prevalence. Some studies have demonstrated a link between the composition of gut microbiota and the increased risk of atherosclerosis, which is the main cause of

\section{Y A-T-IL UNE IMPLICATION DE MICROBIOTA INTESTINAL DANS LES MALADIES CARDIOVASCULAIRES?}

De nos jours, de plus en plus de preuves suggèrent une interrelation entre le microbiote intestinal et les maladies cardiovasculaires. Le microbiote intestinal est composé d'un grand nombre de microorganismes qui vivent dans l'intestin et participent à de nombreux processus physiologiques. Des modifications de la composition et de l'activité du microbiote intestinal peuvent entraîner ou accélérer l'évolution de certaines maladies cardiovasculaires. Des modifications dans la composition du microbiote intestinal vont induire une dysbiose, provoquant une inflammation et initiant le développement de maladies cardiovasculaires. Ces altérations peuvent être secondaires à des infections intestinales, à l'exposition à certains facteurs environnementaux, à des changements d'habitudes alimentaires, à un stress élevé, à l'utilisation d'antibiotiques. Des études ont montré que le microbiote intestinal était composé de six familles: Firmicutes, Bacteroidetes, Proteobacteria, Actino-bacteria, Fusobacteria, et Verrucomicrobia phyla ${ }^{1}$. Ces microorganismes sont impliqués dans les processus immunitaires de l'hôte, dans la lutte contre les microorganismes pathogènes et dans le maintien de l'intégrité des barrières intestinales.

La coronaropathie et l'hypertension artérielle sont des maladies chroniques à prévalence élevée. 
coronary heart disease ${ }^{2,3}$. These studies have identified different species of bacteria, both in the gut and in the atheromatous plaques, suggesting that gut is a source of atherogenic bacteria ${ }^{2,3}$. The mechanisms by which these bacteria can initiate the atherosclerotic process (or in some cases protect against it) are still unknown. Trimethylamine $\mathrm{N}$-oxide (TMAO) is a microbial metabolite that was studied for its effects on cardiovascular diseases after the discovery of a positive correlation between the serum level of TMAO and the atherosclerotic plaque area. This correlation was partially explained by the role that TMAO plays in the inhibition of reverse cholesterol transport and the accumulation of macrophage cholesterol ${ }^{4,5}$. One study has found that the TMAO level in patients with an acute coronary syndrome is an independent predictor of short-term and long-term major adverse cardiac events ${ }^{6}$.

The implication of gut microbiota in arterial hypertension has been demonstrated by animal studies ${ }^{7,8}$. Adnan et al have shown that the blood pressure can be influenced by the exchange of gut microbiota between spontaneously hypertensive rats and Wistar-Kyoto rats? The ratio of Firmicutes and Bacteroidetes is considered specific for intestinal dysbiosis'. In animal studies, the alteration of this ratio correlated with arterial hypertension, suggesting that gut microbiota could be a potential target of future antihypertensive therapies 9 .

Heart failure is the final stage of evolution of the majority of cardiovascular diseases, with high mortality rates. One study has comparatively analyzed the bacteria and fungi in the feces of patients with heart failure with those of healthy controls and demonstrated that patients with chronic heart failure have more pathogenic bacteria ${ }^{10}$. Moreover, some species, like Candida, Shigella, and Campylobacter, were positively correlated with the severity of the heart failure ${ }^{10}$. Patients with heart failure, with decreased cardiac output, have gastrointestinal mucosa congestion and ischemia, with subsequent alterations in the composition of gut microflora and also intestinal functions. These alterations will lead to bacterial translocation, the release of endotoxins in the circulation, promoting a systemic inflammatory response. Some authors suggested that TMAO can be used as a biomarker for prognosis stratification in patients with heart failure ${ }^{11}$, although the exact mechanisms of increased levels of TMAO in patients with heart failure are still unknown. Other gut microbiota metabolites, p-cresyl sulfate and phenylacetylglutamine, have been suggested by some studies to be involved in the appearance of cardiovascular diseases ${ }^{12,13}$.

Based on the above findings, the future cardiovascular therapies may include gut microbiota and
Certaines études ont mis en évidence un lien entre la composition du microbiote intestinal et le risque accru d'athérosclérose, principale cause des maladies coronariennes ${ }^{2,3}$. Ces études ont identifié différentes espèces de bactéries, à la fois dans l'intestin et dans les plaques athéromateuses, suggérant que l'intestin est une source de bactéries athérogènes ${ }^{2,3}$. Les mécanismes par lesquels ces bactéries peuvent initier le processus athérosclérotique (ou, dans certains cas, protéger contre celui-ci) sont encore inconnus. La $\mathrm{N}$-oxyde de triméthylamine (TMAO) est un métabolite microbien qui a été étudié pour ses effets sur les maladies cardiovasculaires, après la découverte d'une corrélation positive entre le taux sérique de TMAO et la plaque athéroscléreuse. Cette corrélation était partiellement expliquée par le rôle joué par la TMAO dans l'inhibition du transport inverse du cholestérol et de l'accumulation de cholestérol macrophage $e^{4,5}$. Une étude a montré que le taux de TMAO chez les patients atteints d'un syndrome coronarien aigu est un facteur prédictif indépendant des événements cardiaques majeurs à court et à long terme ${ }^{6}$.

L'implication du microbiome intestinal dans l'hypertension artérielle a été démontrée par des études chez l'animal ${ }^{7,8}$. Adnan et al ont montré que l'échange de microbiote intestinal entre des rats spontanément hypertendus et des rats Wistar-Kyoto ${ }^{7}$ pouvait influer sur la tension artérielle. Le ratio Firmicutes/Bacteroidetes est considéré spécifique à la dysbiose intestinale? . Dans les études chez l'animal, la modification de ce rapport était corrélée à l'hypertension artérielle, ce qui suggère que le microbiote intestinal pourrait être une cible potentielle des futurs traitements antihypertenseurs ${ }^{9}$.

L'insuffisance cardiaque est la dernière étape de l'évolution de la majorité des maladies cardiovasculaires, avec un taux de mortalité élevé. Une étude a comparé les bactéries et les champignons présents dans les matières fécales des patients insuffisants cardiaques à celles des témoins sains et a montré que les patients insuffisants cardiaques chroniques étaient plus contaminés par des bactéries pathogènes ${ }^{10}$. De plus, certaines espèces, comme Candida, Shigella et Campylobacter, étaient positivement corrélées à la sévérité de l'insuffisance cardiaque ${ }^{10}$. Les patients atteints d'insuffisance cardiaque, présentant un débit cardiaque réduit, présentent une congestion de la muqueuse gastro-intestinale et une ischémie, avec des modifications ultérieures de la composition de la microflore intestinale ainsi que des fonctions intestinales. Ces altérations entraîneront une translocation bactérienne, la libération d'endotoxines dans la circulation, favorisant une réponse inflammatoire systémique. Certains auteurs ont suggéré que le TMAO puisse être utilisé comme biomarqueur 
their metabolites as potential targets. These therapies could be represented not only by drugs but also by diet changes and supplementation with prebiotics and/or probiotics. pour la stratification pronostique chez les patients insuffisants cardiaques ${ }^{11}$, bien que les mécanismes exacts d'augmentation des taux de TMAO chez les patients insuffisants cardiaques soient encore inconnus. Certaines études ont suggéré que d'autres métabolites du microbiote intestinal, le sulfate de p-crésyle et la phénylacétylglutamine, seraient impliqués dans l'apparition de maladies cardiovasculaires ${ }^{12,13}$.

Sur la base des résultats ci-dessus, les futurs traitements cardiovasculaires pourraient inclure le microbiote intestinal et leurs métabolites comme cibles potentielles. Ces thérapies pourraient être représentées non seulement par des médicaments, mais également par des changements de régime et une supplémentation en prébiotiques et/ou probiotiques.

\section{„No conflict of interest.“}

\section{References}

1. Eckburg PB, Bik EM, Bernstein CN, et al. Diversity of the human intestinal microbial flora. Science. 2005;308:1635-1638.

2. Ott SJ, El Mokhtari NE, Musfeldt M, et al. Detection of diverse bacterial signatures in atherosclerotic lesions of patients with coronary heart disease. Circulation. 2006;113:929-937.

3. Koren O, Spor A, Felin J, et al. Human oral, gut, and plaque microbiota in patients with atherosclerosis. Proc Natl Acad Sci USA. 2011;108:4592-4598.

4. Wang Z, Klipfell E, Bennett BJ, et al. Gut flora metabolism of phosphatidylcholine promotes cardiovascular disease. Nature. 2011;472:57-63.

5. Koeth RA, Wang Z, Levison BS, et al. Intestinal microbiota metabolism of L-carnitine, a nutrient in red meat, promotes sclerosis. Nat Med. 2013;19:576-585.

6. Li XS, Obeid S, Klingenberg R, et al. Gut microbiota-dependent trimethylamine N-oxide in acute coronary syndromes: a prognostic marker for incident cardiovascular events beyond traditional risk factors. Eur Heart J. 2017;38:814-824.

7. Adnan S, Nelson JW, Ajami NJ, et al. Alterations in the gut microbiota can elicit hypertension in rats. Physiol Genomics. 2017;49:96-104

8. Yang T, Santisteban MM, Rodriguez V, et al. Gut dysbiosis is linked to hypertension. Hypertension. 2015;65:1331-1340.

9. Sanz Y, Moya-Pérez A. Microbiota, inflammation and obesity. Adv Exp Med Biol. 2014;817:291-317.

10. Pasini E, Aquilani R, Testa C, et al. Pathogenic gut flora in patients with chronic heart failure. JACC Heart Failure. 2016;4:220-227.

11. Tang WH, Wang Z, Fan Y, et al. Prognostic value of elevated levels of intestinal microbe-generated metabolite trimethylamine-N-oxide in patients with heart failure: refining the gut hypothesis. J Am Coll Cardiol. 2014;64:1908-1914.

12. Lin CJ, Chuang CK, Jayakumar T, et al. Serum p-cresyl sulfate predicts cardiovascular disease and mortality in elderly hemodialysis patients. Arch Med Sci. 2013;4:662-668.

13. Poesen R, Claes K, Evenepoel P, et al. Microbiota-derived phenylacetylglutamine associates with overall mortality and cardiovascular disease in patients with CKD. J Am Soc Nephrol. 2016;27:3479-3487. 